\title{
Macrocytic anaemia due to copper deficiency in a patient with late onset hypogammaglobulinaemia
}

\author{
Stephen M. Oppenheimer, ${ }^{1}$ B.I. Hoffbrand, ${ }^{1}$ T.L. Dormandy, ${ }^{2}$ N. Parker ${ }^{3}$ and \\ D.G. Wickens ${ }^{2}$
}

Departments of ${ }^{l}$ Medicine ${ }^{2}$ Clinical Chemistry and ${ }^{3}$ Haematology, Whittington Hospital, Highgate Hill, London, $N 195 N F, U K$.

\begin{abstract}
Summary: Very few cases of acquired severe copper deficiency have been described. The principal effects are haematological, but the precise abnormalities are uncertain due to the possible association of other deficiencies. A case of isolated severe copper deficiency associated with late onset hypogammaglobulinaemia is reported in which the chief findings were macrocytic anaemia, neutropenia and a decrease in mean platelet volume. All these abnormalities resolved when copper therapy was instituted and recurred when the medication was stopped.
\end{abstract}

\section{Introduction}

Acquired severe copper deficiency is exceptionally rare. ${ }^{1,2}$ Reported cases fall principally into two categories, severely malnourished infants ${ }^{3-5}$ and adults receiving total parenteral nutrition. ${ }^{6-9}$ There have been two case reports of copper deficiency in well-nourished infants ${ }^{10,11}$ and severe copper deficiency induced by ingestion of large doses of zinc ${ }^{12}$ has been described. We report a case of severe copper deficiency in an adult with late-onset hypogammaglobulinaemia, an association not previously noted.

\section{Case report}

A 76 year old female presented with diarrhoea of one year's duration. There was a history of pernicious anaemia, which had been diagnosed 15 years previously, and of hyperthyroidism, diagnosed 50 years ago. Apart from monthly hydroxocobalamin injections she was receiving no medication.

On examination, she was generally wasted and of small stature. The skin, joints, hair and central nervous system were normal. The normal biochemical findings included plasma urea and electrolytes, liver function tests, blood glucose and thyroid function. She was hypocalcaemic $(1.77 \mathrm{mmol} / \mathrm{l})$, hypophosphataemic $(0.37 \mathrm{mmol} / \mathrm{l})$ and the plasma alkaline phosphatase was raised at 230 units. The albumin was $41 \mathrm{~g} / 1$ and total protein $56 \mathrm{~g} / \mathrm{l}$. The 25 -hydroxycholecalciferol level was $3.0 \mathrm{ng} / \mathrm{ml}$ (normal 3.0-30),

Correspondence: N. Parker, M.R.C.P., M.R.C.Path. Accepted: 25 September 1986 parathyroid hormone $60 \mathrm{pg} / \mathrm{ml}$ (normal under 120) and serum magnesium $0.69 \mathrm{mmol} / \mathrm{l}(0.70-1.00)$. Haemoglobin $(\mathrm{Hb})$ was $10.5 \mathrm{~g} / \mathrm{dl}$ with occasional spherocytes present on the film. Other haematological findings were:- PCV 32, MCV $97 \mathrm{fl}, \mathrm{MCHC} 32.7 \mathrm{~g} / \mathrm{dl}$, MCH $31.6 \mathrm{pg}$, white blood cells $10.7 \times 10^{9} / 1$ (neutrophils $68 \%$, lymphocytes $24 \%$, monocytes $5 \%$, eosinophils $3 \%$ ); platelets $421 \times 10^{9} / 1$; Coombs' test negative; serum $B_{12} 940 \mathrm{ng} / \mathrm{l}(160-960)$; serum folate $4.5 \mu \mathrm{g} / 1(3-18)$; serum iron $9.0 \mu \mathrm{mol} / 1(11-32)$ and total iron binding capacity (TIBC) $60 \mu \mathrm{mol} / 1(35-70)$. Her serum copper was $4.2 \mu \mathrm{mol} / 1(11-22)$, caeruloplasmin $0.06 \mathrm{~g} / \mathrm{l}(0.20-0.40)$ and zinc $10.1 \mu \mathrm{mol} / 1$ $(11.5-17)$. The autoantibody profile was negative; the immunoglobulin levels were grossly reduced - IgG $1.6 \mathrm{~g} / 1(8.0-18.0) ; \mathrm{IgA}<0.1 \mathrm{~g} / 1(0.9-4.5), \operatorname{IgM} 0.1 \mathrm{~g} / 1$ $(0.6-2.8)$.

A chest X-ray and skeletal survey were normal as was a small bowel enema. Stool culture grew campylobacter and jejunal aspirate was unremarkable. Jejunal biopsy revealed partial villous atrophy with a chronic inflammatory infiltrate of eosinophils and a few plasma cells. The 3 day faecal fat collection was $42 \mathrm{mmol} / 24 \mathrm{~h}$ (normal 10-18). The stool was repeatedly negative for occult blood.

A malabsorptive state secondary to bacterial overgrowth was diagnosed, in a patient with late-onset hypogammaglobulinaemia. The histological changes were considered to be secondary to bacterial overgrowth although a diagnosis of concomitant coeliac disease was not entirely excluded at this time. She was treated with gammaglobulin injections $25 \mathrm{mg} / \mathrm{kg}$ / week, folic acid, and a course of erythromycin, on 
which regimen her diarrhoea ceased. She was also commenced on high dose oral vitamin $\mathrm{D}$, with resolution of the hypocalcaemia and normalization of the alkaline phosphatase level.

Over the next 2 months the blood count continued to show a mild normochromic normocytic anaemia but 5 months after initial investigation, she developed a macrocytic anaemia ( $\mathrm{Hb} 8.3 \mathrm{~g} / \mathrm{dl}, \mathrm{MCV} 103 \mathrm{fl})$ and was neutropenic $\left(2.3 \times 10^{9} / 1\right)$. Her diarrhoea had returned previously and she was anorexic. Subsequently her haemoglobin showed a progressive decline (Figure 1) and blood films revealed macrocytosis with red cell fragments and bizarre forms. The reticulocyte count was $4.6 \%$, serum $B_{12}$ was $620 \mathrm{ng} / 1$ and serum folate $18 \mu \mathrm{g} / \mathrm{l}$, serum iron $6.0 \mu \mathrm{mol} / 1$ and TIBC $39.0 \mu \mathrm{mol} / 1$. Bone marrow examination revealed normal cellularity with normoblastic erythropoiesis but early white cell precursors had a vacuolated cytoplasm, with occasional late forms showing defective granulation. The iron stores were normal. No ringed sideroblasts were seen. The trephine biopsy was unremarkable.

Serum copper and caeruloplasmin were now (Feb and Mar 1985) less than $1 \mu \mathrm{mol} / 1$ and $0.03 \mathrm{~g} / 1$ respectively, both undetectable by conventional laboratory analysis. The red cell copper was $3.7 \mu \mathrm{mol} / 1$ (normal 12.9-15.9) and red cell superoxide dismutase 267

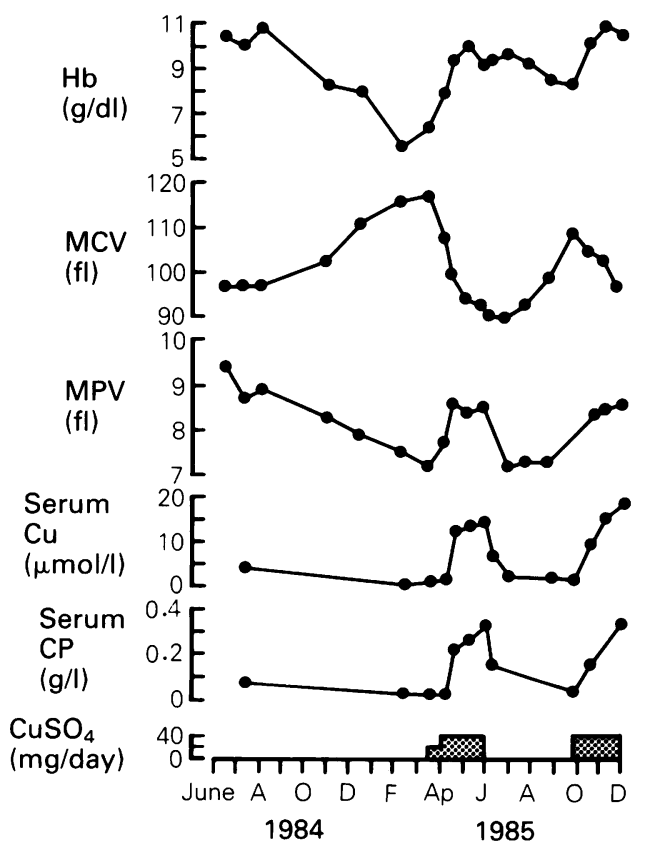

Figure 1 Correction of anaemia and macrocytosis by oral copper sulphate on two occasions in a patient with late onset hypogammaglobulinaemia. $\mathrm{Hb}=$ haemoglobin; $\mathrm{MCV}=$ mean red cell volume; $\mathrm{MPV}=$ mean platelet volume; $\mathbf{C P}=$ caeruloplasmin. units/ml erythrocytes (normal 599-675). She was considered grossly copper deficient and commenced on an aqueous suspension of copper sulphate $20 \mathrm{mg}$ increased to $40 \mathrm{mg}$ by mouth daily. After one month there was a dramatic improvement in her haemoglobin, with reduction in the $\mathrm{MCV}$ and a concomitant reticulocytosis as serum copper and caeruloplasmin values rose (Figure 1). The red cell copper rose to $9.8 \mu \mathrm{mol} / 1$. The mean platelet volume increased with treatment and the platelet count rose to $737 \times 10^{9} / 1$. The white cell count reached $12.4 \times 10^{9} / 1$ (neutrophils $66 \%$ ). Permission for a repeat bone marrow examination was refused. The copper was stopped after 6 weeks with a subsequent gradual decline in haemoglobin and increase in MCV. A fall in white cell and neutrophil counts also occurred but not to the previous neutropaenic levels. Owing to persistent weight loss and anorexia, a gluten-free diet was introduced three weeks after copper therapy ceased, with no effect on the haematological or clinical course. Permission for a second jejunal biopsy and aspirate was refused. Four months later (approximately 3 months after the institution of the gluten-free diet) copper sulphate $40 \mathrm{mg}$ by mouth was reintroduced and continued for 2 months. There was a subsequent improvement in the haematological indices (Figure 1) which continued until her death at home frong $\overrightarrow{0}$ inanition in November, 1985.

\section{Discussion}

In induced copper deficiency, the various copper pools in the body become depleted in a hierarchical manner. Caeruloplasmin copper declines first; copper in tyrosinase and other amino acid oxidases follows and only after cytochrome copper begins to be depleted does red cell superoxide dismutase activity copper decrease. The low red cell superoxide dismutase acitivity in this patient therefore indicates the extreme severity of her copper deficiency. ${ }^{13}$

Previous reports have stressed the occurrence of a microcytic hypochromic anaemia compatible with either iron deficiency or an abnormality in iron utilization..$^{2,5,14}$ These patients all suffered from multiple haematinic deficiencies secondary to malnutrition $\frac{T}{O}$ or malabsorption. In many cases, serum levels were not recorded $^{2,3,5}$ and partial responses to other $N$ haematinics occurred ${ }^{3}$ before the introduction of copper. In the present case, the anaemia was macrocytic $N$ with normoblastic erythropoiesis. The anaemia and $\omega$ macrocytosis were corrected on two occasions by oral 2 copper sulphate.

Macrocytosis has been observed previously in copper deficiency complicating malnutrition. In two ? reports ${ }^{3,7}$ serum $B_{12}$ and folate levels were not given and in two others ${ }^{8,9}$ they were normal. In the latter, bone 
marrow histology showed megaloblastic ${ }^{8}$ and megaloblastoid ${ }^{9}$ changes, resolving with copper administration alone.

Reported marrow findings in copper deficiency include normal red cell maturation, ${ }^{3}$ as in our patient, and ringed sideroblasts. ${ }^{4,9}$ The white cell line has shown variously giant metamyelocytes, ${ }^{3,15}$ quantitative diminution with a predominance of mature elements ${ }^{3}$ or maturation arrest. ${ }^{8,10}$ Striking vacuolation of erythroid $^{3,10}$ or both erythroid and myeloid ${ }^{4,8,9}$ cell lines has been seen. Our patient showed vacuolation of the myeloid series as well as maturation arrest of myelopoiesis. Most reports agree on the occurrence of neutropaenia in copper deficiency, ${ }^{1,2,15}$ and this is confirmed in the present study. The apparent effect on platelet size has not been previously reported.

The role of copper in haemopoiesis is not known. Studies in pigs have suggested that copper is necessary both for the absorption of iron and its transfer from the reticulo-endothelial system to the marrow, ${ }^{17}$ accounting for the microcytic hypochromic anaemia observed. Subsequent investigations however have shown that porcine hypocupraemic anaemia can develop independently of serum and marrow iron levels. ${ }^{18}$ Similarly macrocytosis and megaloblastoid maturation, together with myeloid maturation arrest and peripheral neutropaenia, cannot be explained in terms of iron deficiency alone. These findings would

\section{References}

1. Williams, D.M. Copper deficiency in humans. Semin Hematol 1983, 20: 118-128.

2. Cartwright, G.E. \& Wintrobe, M.M. The question of copper deficiency in man. Am J Clin Nutr 1964, 15: 94110.

3. Cordano, A., Baertl, J.M. \& Graham, G.G. Copper deficiency in infancy. Pediatrics 1964, 34: 324-336.

4. Ashkenazi, A., Levin, S., Djaldetti, M., Fishel, E. \& Benvenisti, $D$. The syndrome of neonatal copper deficiency. Pediatrics 1973, 52: 525-533.

5. Graham, G.C. \& Cordano, A. Copper depletion and deficiency in the malnourished infant. Johns Hopkins Med J 1969, 124: 139-150.

6. Karpel, J.T. \& Peden, V.H. Copper deficiency in longterm parenteral nutrition. J Pediatr 1972, 80: 32-36.

7. Vilter, R.W., Bozian, R.C., Hess, E.V., Zellner, D.C. \& Petering, H. Manifestations of copper deficiency in a patient with systemic sclerosis on intravenous hyperalimentation. $N$ Engl J Med 1974, 291: 188-191.

8. Zidar, B.L., Shadduck, R.K., Ziegler,Z. \& Winkelstein, A. Observations on the anemia and neutropenia of human copper deficiency. Am J Haematol 1977, 3: 177185.

9. Dunlop, W.M., James, G.W. \& Hume, D.M. Anemia and neutropenia caused by copper deficiency. Ann Intern Med 1974, 80: 470-476.

10. Al-Rashid, A. \& Spangler, J. Neonatal copper deficiency. $N$ Engl J Med 1971, 285: 841-843. be consistent with a role of copper as a cofactor for enzymes involved in either cell division or protein synthesis within the marrow.

There have been no previous reports of hypocupraemia associated with hypogammaglobulinaemia in man, but a striking association between induced copper deficiency and the suppression of the immune response has been described in mice. ${ }^{19}$ This appears to be a specific copper effect, unrelated to zinc deficiency or the associated iron-deficiency anaemia. Our patient had normal $\mathrm{T}$ cell subsets in blood and marrow prior to copper treatment and no increase in immunoglobulin levels after 6 weeks' replacement. The probable causes of copper deficiency in this case were the malabsorptive state and anorexia. The duodenal histological changes did not suggest coeliac disease in which copper deficiency has been reported, ${ }^{2}$ and a gluten-free diet alone failed to improve the haematological status.

We believe this case demonstrates the haematological features of isolated severe copper deficiency in man. It should encourage blood copper level estimation in otherwise unexplained macrocytic anaemia.

\section{Acknowledgement}

We are grateful to Dr A.D.B. Webster for supplies of gammaglobulin and for helpful comments.
11. Levy, Y., Zeharia, A., Grunebaum, M., Nitzan, M. \& Steinherz, R. Copper deficiency in infants fed cow milk. $J$ Pediatr 1985, 106: 786-788.

12. Patterson, W.P., Winkelmann, M. \& Perry, M.C. Zinc induced copper deficiency: megamineral sideroblastic anaemia. Ann Intern Med 1985, 103: 385-386.

13. Gutteridge, J.M.S. \& Stocks, J. Caeruloplasmin. CRC Crit Rev Clin Lab Sci 1981, 14: 257-329.

14. Cartwright, G.E. The relationship of copper, cobalt and other trace elements to hemopoiesis. Am J Clin Nutr 1955, 3: 11-17.

15. Cordano, A. \& Graham, G. Copper deficiency complicating severe chronic intestinal malabsorption. Pediatrics 1966, 38: 596-604.

16. Cordano, A., Placko, R.P. \& Graham, G.G. Hypocupremia and neutropenia in copper deficiency. Blood 1966, 28: 280-282.

17. Lahey, M.E., Gubler, D.J., Chase, M.S., Cartwright, G.E. \& Wintrobe, M.M. Studies in copper metabolism. II Hematologic manifestations of copper deficiency in swine. Blood 1952, VII: 1053-1071.

18. Lee, G.R., Nacht, S., Lukens, J.N. \& Cartwright, G.E. Iron metabolism in copper deficient swine. J Clin Invest 1968, 47: 2058-2069.

19. Prohaska, J.R. \& Lukasewycz, O. Copper deficiency suppresses immune response in mice. Science 1981, 213: $559-562$. 